\title{
Conservation begins after breakfast: The relative importance of opportunity cost and identity in shaping private landholder participation in conservation
}

\author{
Beatrice Conradie ${ }^{\mathrm{a}, *}$, Martina Treurnicht $^{\mathrm{b}}{\text {, } \text { Karen Esler }^{\mathrm{c}} \text {, Mirijam Gaertner }}^{\mathrm{d}}$ \\ ${ }^{a}$ School of Economics and Centre for Social Science Research, University of Cape Town, Private Bag X1, Rhodes Gift 7703, South Africa \\ ${ }^{\mathrm{b}}$ Department of Conservation Ecology and Entomology, Stellenbosch University, Private Bag X1, Matieland 7602, South Africa \\ ${ }^{\mathrm{c}}$ Department of Conservation Ecology and Entomology and Centre of Invasion Biology, Stellenbosch University, Private Bag X1, Matieland 7602, South Africa \\ ${ }^{\mathrm{d}}$ Centre of Invasion Biology, Stellenbosch University, Private Bag X1, Matieland 7602, South Africa
}

\section{A R T I C L E I N F O}

\section{Article history:}

Received 14 December 2011

Received in revised form 23 August 2012

Accepted 27 August 2012

\section{Keywords:}

Conservation on private land

Opportunity cost

Agriculture

Cape Floristic Region

\begin{abstract}
A B S T R A C T
The conservation opportunity literature increasingly emphasises opportunity cost as an important determinant of willingness to engage in conservation on private land. We investigated the explanatory power of a group of opportunity cost variables in the decision to participate in a landscape-level conservation initiative on the Agulhas Plain, Cape Floristic Region. Opportunity cost variables outperformed affiliation and demographic variables when used in one model and had almost as much explanatory power as the combined model when used on their own. In the opportunity cost model, conservation was positively related to farm size and education and negatively related to share of income from farming and size of the remnant of natural vegetation on the farm. Of these relationships, that between education and participation was the most elastic: a $1 \%$ increase in education led to an almost $2 \%$ increase in the likelihood of participating in conservation. A large group of identity variables jointly explained nothing, but a subset of age, gender and Afrikaans language status had some explanatory power when used separately. We suspected this subset of demographic variables to have done nothing but proxy patterns of opportunity cost in the farming community. When re-estimated with the untransformed remnant as a share of farm size rather than an area, similar results were obtained and the negative sign on the remnant was confirmed. We concluded that understanding what opportunity cost conservation imposes on private landholders is not only important, but critical, for predicting which private land will come into and stay in conservation. (c) 2012 Elsevier Ltd. All rights reserved.
\end{abstract}

\section{Introduction}

It is common cause internationally that land of low economic value is over-represented in protected areas (e.g. Pressey, 1994; Balmford and Whitten, 2003), leaving high priority conservation land at the mercy of private landholders (Knight, 1999). Private land should ideally become part of conservation plans, because the statutory protected areas are insufficient to protect biodiversity effectively (Brooks et al., 2004; Rodriques et al., 2004). Biodiversity targets could be achieved at significantly lower cost by incorporating private conservation land into the global network of protected areas (Gallo et al., 2009). But for this strategy to be successful, it is important to explore which farmers are likely to sign up for conservation and what schemes and programmes have the greatest chance of success (Knight et al., 2011; Raymond and Brown, 2011; Michael, 2003).

When private landholders on the Agulhas Plain in the Cape Floristic Region claim that "conservation begins after breakfast" they im-

\footnotetext{
* Corresponding author. Tel.: +27 21 6502731; fax: +27 216502854 .

E-mail address: beatrice.conradie@uct.ac.za (B. Conradie).
}

ply that conservation is a luxury which has to wait until the urgent work of farming is done. Australian cattle farmers expressed the same sentiments with the assertion that "it is hard to be green when you are in the red" (Richards et al., 2005). If these claims accurately reflect how most farmers predominantly think about conservation, it means that participation in conservation is a matter of affordability and forgone income, and is not primarily determined by attitude or identity. Several multivariate conservation models include elements of opportunity cost (Sekhar, 2003; Shrestha and Alavalapati, 2006; Ma et al., 2009; Cross et al., 2011), but none of these models test opportunity cost variables explicitly against other (identity) variables. We do not present this paper as a choice between opportunity cost and identity; we simply want to understand the extent to which opportunity cost variables can provide, or contribute to, an explanation of conservation on private farmland.

\section{Methods}

\subsection{Study area}

The setting for this study is the Agulhas Biodiversity Initiative, a landscape-level conservation initiative rolled out across an area of 
335,335 ha of private farmland on the Agulhas Plain, South Africa, in the early 2000s. The Initiative aimed to promote sustainable resource use, strengthen conservation partnerships and raise general conservation awareness (Lochner et al., 2003). Its broad intended impact meant that landowners encountered the work of the Initiative in a number of contexts. For example, some landholders were recruited into a sustainable wildflower harvesting certification programme, while others were involved in the establishment of a private protected area.

The Agulhas Plain (S34 $40^{\prime}$ E19 ${ }^{\circ} 40^{\prime}$ ) is exceptionally rich in biodiversity, including 1751 plant species, among them 99 endemics and 112 Red Data Book species (Cowling and Holmes, 1992; Cowling and Mustart, 1994; Raimondo et al., 2009). Biodiversity is threatened by agriculture and urbanisation, which have already transformed $23 \%$ of the land, and invasive alien vegetation, which has claimed at least $11 \%$ of the land and continues to spread (Lombard et al., 1997). More than $70 \%$ of the land is in private hands. Traditional farming enterprises, such as mixed livestock-grain and dairy farming, account for $42 \%$ of the average landholder's household income, while $25 \%$ of income derives from biodiversity businesses such as wildflower harvesting (Conradie, 2010). The survey recorded off-farm income as contributing $34 \%$ of the average household's income in the sample. Most of the off-farm income derives from lifestyle or hobby farms, but in a handful of cases it indicates subsistence farms. The main growth sectors within traditional agriculture are dairy, grains and wine grapes. The majority of farmers are male, white and Afrikaans-speaking.

\subsection{Data collection}

Data were collected during semi-structured, face-to-face interviews in the winter of 2009. We collected information about the farmer, the farm and the farmer's involvement in the Agulhas Biodiversity Initiative. The membership lists of four local chapters of the farmers' union were used in combination with contact details provided by neighbours and NGOs working in the area to compile a population of rural landholders from which a random sample of was drawn. Our interviews targeted owner-operators or senior farm managers and on occasion we interviewed husband and wife together. Interviews were conducted in the home of the respondent. To maximise the response rate, we phoned ahead to make appointments and used a single Afrikaans-speaking interviewer with a background in agriculture and a good knowledge of the area. The sample of 75 observations corresponds to a response rate of $82 \%$ of farms sampled and represents $73 \%$ land coverage on the Agulhas Plain. Sample size was restricted by the small scope of the Initiative, which limited the complexity of the multivariate regression models presented below. Significant non-response on variables like income and farm size was a further challenge to the model building process.

\subsection{Model specification}

Previous studies have used pair-wise tests and multivariable modelling to distinguish landholders who are willing to engage in conservation and those who are not. If sample size is limited, pair-wise tests are an attractive option, but where sample size is large enough, multivariable models have the advantage of showing the interaction between various potential determinants of willingness to conserve. Both approaches were used in this study in order check for internal consistency. For pair-wise testing, the process was to categorise landholders according to their conservation status or attitudes and then to test for significant differences in farm and farmer characteristics across the categories, one characteristic at a time. In multivariate models the dependent variable usually measures attitudes (Sekhar, 2003; Shrestha and Alavalapati,
Table 1

Definitions of exogenous variables with expected signs.

\begin{tabular}{|c|c|c|}
\hline Name & Variable description & $\begin{array}{l}\text { Expected } \\
\text { sign }\end{array}$ \\
\hline \multicolumn{3}{|c|}{ Opportunity cost variables } \\
\hline $\ln (\operatorname{size})$ & Natural log of hectares of all land & + \\
\hline $\begin{array}{l}\text { \%farm } \\
\text { income }\end{array}$ & $\begin{array}{l}\text { Share of household income from traditional } \\
\text { farming enterprises }\end{array}$ & - \\
\hline $\ln$ (education) & Natural log of years of formal schooling & + \\
\hline $\ln ($ remnant $)$ & Natural log of hectares of untransformed land & $-1+$ \\
\hline \%remnant & $\begin{array}{l}\text { The untransformed remnant as a share of farm } \\
\text { size }\end{array}$ & $+1-$ \\
\hline \multicolumn{3}{|c|}{ Identity variables } \\
\hline $\begin{array}{l}\ln (\text { family } \\
\text { tenure })\end{array}$ & Natural log of years of family tenure on the land & + \\
\hline $\begin{array}{l}\text { Farmers } \\
\quad \text { union D }\end{array}$ & $\begin{array}{l}\text { Dummy variable }=1 \text { if farmers' union member, } \\
\text { else }=0\end{array}$ & - \\
\hline $\begin{array}{l}\text { Conservancy } \\
\text { D }\end{array}$ & $\begin{array}{l}\text { Dummy variable = } 1 \text { if conservancy member, } \\
\text { else }=0\end{array}$ & + \\
\hline Tourism D & $\begin{array}{l}\text { Dummy variable }=1 \text { if involved in eco-tourism } \\
\text { enterprise, else }=0\end{array}$ & + \\
\hline $\begin{array}{l}\text { PA proximity } \\
\quad \text { D }\end{array}$ & $\begin{array}{l}\text { Dummy variable }=1 \text { if holding land next to } \\
\text { protected area, else }=0\end{array}$ & - \\
\hline $\ln ($ age $)$ & Natural log of age in years & - \\
\hline Gender D & Dummy variable $=1$ if male, else $=0$ & - \\
\hline Language D & $\begin{array}{l}\text { Dummy variable = } 1 \text { if Afrikaans-speaking, } \\
\text { else }=0\end{array}$ & - \\
\hline
\end{tabular}

2006; Cross et al., 2011) or the adoption of a given strategy (Ma et al., 2009). The dependent variable in this study was self-reported participation in any of the Agulhas Biodiversity Initiative's conservation activities. The response was binary. Where respondents were unsure of what the Initiative was, participation was recorded as no. No attempt was made to quality-adjust for extent of participation. The variation in the likelihood of participating in the work of the Agulhas Biodiversity Initiative was explained using the variables defined in Table 1.

The opportunity cost hypotheses were formulated as follows: farm size was used as a proxy for income and share of income from agriculture was used to control for the degree to which farm size could capture household income. The higher income, the more affordable conservation was hypothesised to be. The expected sign on share of income from agriculture (\%farm income) was negative, as receiving less income from the land would lower the opportunity cost of conserving it. We expected education to be positively correlated with conservation for two related opportunity cost reasons: only better educated professional people can afford hobby farms, and if commercial farmers were to set aside land for conservation, better educated farmers would find off-farm work more easily than the less educated ones. Two options were considered for the specification of the remnant variable, namely area and proportion of total farm size. When defined as an area, the sign on the remnant variable was hypothesised to be negative, as larger remnants would imply more foregone production when switched into conservation. Alternatively, larger remnants would also represent more critical mass for starting up conservation compatible enterprises, in which case its relationship with conservation would be positive. Winter et al. (2005) reported a positive, but insignificant, relationship between the remnant area and conservation attitudes. The same arguments applied to the\%remnant variable, except that very high remnant shares would almost certainly indicate hobby farms on which the opportunity cost of conservation was low. Therefore\% remnant was expected to be positively related to conservation. The main advantage of the remnant share specification was that it was likely to be uncorrelated with farm size, while the remnant area specification was likely to be highly correlated with farm size. 
Table 2

Profiles of participants and non-participants in the Agulhas Biodiversity Initiative.

\begin{tabular}{|c|c|c|c|c|}
\hline \multirow[t]{2}{*}{ Farm and farmer characteristic } & \multicolumn{2}{|c|}{ Participation } & \multirow[t]{2}{*}{ Tests of significance } & \multirow[t]{2}{*}{$p$-Value } \\
\hline & $\begin{array}{l}\text { No } \\
n=49\end{array}$ & $\begin{array}{l}\text { Yes } \\
n=26\end{array}$ & & \\
\hline \multicolumn{5}{|l|}{ Opportunity cost variables } \\
\hline Farm size (ha) & 1472 & 1943 & $t_{73}=0.764$ & 0.448 \\
\hline \%farm income & $48 \%$ & $30 \%$ & $t_{73}=1.798^{\dagger}$ & 0.076 \\
\hline Education (years) & 11 & 14 & $t_{73}=4.392^{* *}$ & 0.000 \\
\hline Remnant (ha) & 967 & 1073 & $t_{73}=0.213$ & 0.832 \\
\hline \%remnant & $53 \%$ & $56 \%$ & $t_{67}=0.398$ & 0.692 \\
\hline \multicolumn{5}{|l|}{ Identity variables } \\
\hline Family tenure (years) & 71 & 58 & $t_{70}=0.821$ & 0.415 \\
\hline Farmers' union D ( 1 = yes) & $78 \%$ & $69 \%$ & $\chi_{1}^{2}=0.622$ & 0.430 \\
\hline Conservancy D ( 1 = yes $)$ & $22 \%$ & $40 \%$ & $\chi_{1}^{2}=2.669$ & 0.102 \\
\hline Tourism D $(1$ = yes $)$ & $6 \%$ & $8 \%$ & $\chi_{1}^{2}=0.069$ & 0.795 \\
\hline PA proximity $\mathrm{D}$ ( 1 = next to park) & $11 \%$ & $28 \%$ & $\chi_{1}^{2}=3.384^{\dagger}$ & 0.066 \\
\hline Age (years) & 51 & 46 & $t_{73}=1.533$ & 0.130 \\
\hline Gender D $(1=$ male $)$ & $82 \%$ & $96 \%$ & $\chi_{1}^{2}=3.100^{\dagger}$ & 0.078 \\
\hline Language D ( 1 = Afrikaans) & $94 \%$ & $77 \%$ & $\chi_{1}^{2}=4.624^{*}$ & 0.032 \\
\hline
\end{tabular}

*** Significant at $p \leqslant 1 \%$.

* Significant at $p \leqslant 5 \%$.

$\dagger$ Significant at $p \leqslant 10 \%$.

For expected relationships between the propensity for conservation and the other explanatory variables listed in Table 1 we looked toward the literature. There was relatively strong evidence that conservancy membership and eco-tourism are markers of conservation-mindedness (Jacobson et al., 2003; Sekhar, 2003; Winter et al., 2005; Lindsey et al., 2005; Cross et al., 2011). We could not distinguish between eco-tourism and other tourism but still hypothesised a positive sign on all tourism given the rural character of the Agulhas Plain. We hypothesised a negative relationship between farmers' union membership and conservation. In the literature the evidence on proximity to a protected area was mixed. Sekhar (2003) found distance from a protected area to reduce positive attitudes to conservation, while Shrestha and Alavalapati (2006) found distance to improve attitudes. The dummy variable for proximity to protected areas was defined as the ownership of land adjacent to nature reserves or national parks. We hypothesised those closer to protected areas to be more likely to participate in conservation than those further away.

To account for outliers the variables measuring farm size, size of the untransformed remnant, years of education, years of family tenure and respondent age were transformed by taking the natural logarithm. For these variables the marginal effect captured an increase in the propensity of conservation of a $1 \%$ increase in the dependent variable. For the\%farm_income and\%remnant variables the marginal effects captured the impact of a one percentage point increase in the independent variable and for dummy variables it captured the effect of switching from zero to one.

As far as possible, we tried to steer clear of factors which were co-determined with participation in the work of the Agulhas Biodiversity Initiative. For example, knowledge of the local or global significance of conservation was likely to be correlated with participation (Ma et al., 2009), but since the direction of causality could go both ways, only pre-project knowledge qualifies as a legitimate explanatory variable. The measurement of environmental knowledge taken at the end of the project therefore could not be used.

\subsection{Analysis}

Pair-wise $t$-tests of means and $\mathrm{chi}^{2}$ tests of distribution were conducted across the participant categories using Stata 10.0. To test for the contribution of opportunity cost variables in explaining

Table 3

Correlation coefficients for explanatory variables, including alternative specifications of size of untransformed remnant and the remnant as a share of farm size.

\begin{tabular}{|c|c|c|c|c|c|c|c|c|c|c|c|c|c|}
\hline & $\begin{array}{c}\text { Farm } \\
\text { size }\end{array}$ & $\begin{array}{l}\% \text { farm } \\
\text { income }\end{array}$ & $\begin{array}{c}\text { Remnant } \\
\text { size }\end{array}$ & $\begin{array}{c}\% \\
\text { remnant }\end{array}$ & Education & $\begin{array}{l}\text { Family } \\
\text { history }\end{array}$ & $\begin{array}{c}\text { Farmers' } \\
\text { union D }\end{array}$ & $\begin{array}{l}\text { Conser- } \\
\text { vancy D }\end{array}$ & $\begin{array}{c}\text { PA } \\
\text { proximity } \\
\text { D }\end{array}$ & $\begin{array}{c}\text { Tourism } \\
\text { D }\end{array}$ & Age & $\begin{array}{c}\text { Male } \\
\text { gender } \\
\text { D }\end{array}$ & $\begin{array}{c}\text { Language } \\
\text { D }\end{array}$ \\
\hline Farm size & 1.000 & & & & & & & & & & & & \\
\hline$\%$ farm income & 0.053 & 1.000 & & & & & & & & & & & \\
\hline Remnant size & 0.866 & -0.092 & 1.000 & & & & & & & & & & \\
\hline$\%$ remnant & 0.253 & -0.3794 & & 1.000 & & & & & & & & & \\
\hline Education & 0.227 & -0.172 & 0.181 & 0.276 & 1.000 & & & & & & & & \\
\hline Family history & 0.228 & 0.214 & 0.082 & -0.310 & -0.343 & 1.000 & & & & & & & \\
\hline Farm union D & 0.074 & 0.384 & 0.022 & -0.209 & -0.054 & 0.045 & 1.000 & & & & & & \\
\hline Conservancy D & 0.008 & -0.241 & 0.074 & 0.227 & 0.258 & -0.142 & 0.015 & 1.000 & & & & & \\
\hline PA proximity D & 0.404 & 0.095 & 0.099 & -0.030 & 0.140 & 0.235 & 0.145 & 0.037 & 1.000 & & & & \\
\hline Tourism D & 0.185 & -0.132 & 0.237 & 0.074 & 0.275 & 0.002 & -0.151 & 0.285 & -0.109 & 1.000 & & & \\
\hline Age & $\begin{array}{c}- \\
0.095\end{array}$ & 0.095 & -0.093 & 0.005 & -0.221 & 0.176 & 0.217 & -0.061 & -0.115 & -0.202 & 1.000 & & \\
\hline Male gender D & 0.104 & 0.066 & 0.051 & -0.137 & -0.061 & 0.163 & 0.065 & 0.069 & 0.136 & -0.140 & 0.129 & 1.000 & \\
\hline Language D & 0.071 & 0.176 & 0.032 & -0.193 & -0.403 & 0.266 & 0.221 & -0.310 & 0.160 & -0.294 & 0.012 & 0.204 & 1.000 \\
\hline
\end{tabular}


Table 4

Estimation results for logit models explaining participation in the Agulhas Biodiversity Initiative.

\begin{tabular}{|c|c|c|c|c|c|c|c|c|c|c|}
\hline & \multicolumn{2}{|l|}{ Combined } & \multicolumn{2}{|c|}{ Opportunity cost } & \multicolumn{2}{|l|}{ Affiliation } & \multicolumn{2}{|c|}{ Demographics } & \multicolumn{2}{|c|}{ Opportunity cost + demographics } \\
\hline & $\begin{array}{l}\text { Coefficient } \\
\text { robust SE }\end{array}$ & $\begin{array}{l}\text { Marginal } \\
\text { effect }\end{array}$ & $\begin{array}{l}\text { Coefficient } \\
\text { robust SE }\end{array}$ & $\begin{array}{l}\text { Marginal } \\
\text { effect }\end{array}$ & $\begin{array}{l}\text { Coefficient } \\
\text { robust SE }\end{array}$ & $\begin{array}{l}\text { Marginal } \\
\text { effect }\end{array}$ & $\begin{array}{l}\text { Coefficient } \\
\text { robust SE }\end{array}$ & $\begin{array}{l}\text { Marginal } \\
\text { effect }\end{array}$ & $\begin{array}{l}\text { Coefficient } \\
\text { robust SE }\end{array}$ & $\begin{array}{l}\text { Marginal } \\
\text { effect }\end{array}$ \\
\hline \multirow[t]{2}{*}{$\ln$ (farm size) } & $1.077^{*}$ & $0.173^{*}$ & $0.721^{*}$ & $0.127^{*}$ & & & & & $0.776^{\dagger}$ & $0.154^{\dagger}$ \\
\hline & 0.472 & & 0.307 & & & & & & 0.417 & \\
\hline \multirow[t]{2}{*}{ \%farm income } & $-1.497^{\dagger}$ & -0.240 & $-1.421^{\dagger}$ & $-0.251^{\dagger}$ & & & & & $-1.632^{*}$ & $-0.323^{\dagger}$ \\
\hline & 0.863 & & 0.731 & & & & & & 0.808 & \\
\hline \multirow[t]{2}{*}{$\ln$ (education) } & $11.96^{* *}$ & $1.922^{* *}$ & $9.197^{* *}$ & $1.624^{* *}$ & & & & & $8.108^{* *}$ & $1.605^{* *}$ \\
\hline & 4.358 & & 2.629 & & & & & & 2.740 & \\
\hline \multirow[t]{2}{*}{$\ln ($ remnant size) } & $-0.561^{*}$ & $-0.090^{*}$ & $-0.344^{*}$ & $-0.061^{\dagger}$ & & & & & $-0.443^{\dagger}$ & $-0.088^{+}$ \\
\hline & 0.257 & & 0.176 & & & & & & 0.267 & \\
\hline \multirow[t]{2}{*}{$\ln$ (family tenure) } & 0.528 & 0.085 & & & -0.209 & -0.045 & & & & \\
\hline & 0.433 & & & & 0.263 & & & & & \\
\hline \multirow[t]{2}{*}{ Farmers' union D } & -0.864 & -0.157 & & & -0.527 & -0.117 & & & & \\
\hline & 0.987 & & & & 0.613 & & & & & \\
\hline \multirow[t]{2}{*}{ Conservancy D } & 1.024 & 0.187 & & & 0.825 & 0.186 & & & & \\
\hline & 0.904 & & & & 0.614 & & & & & \\
\hline \multirow[t]{2}{*}{ Tourism D } & $-4.494^{* *}$ & $-0.237^{* *}$ & & & 0.469 & 0.107 & & & & \\
\hline & 1.683 & & & & 1.047 & & & & & \\
\hline \multirow[t]{2}{*}{ PA proximity D } & -1.066 & -0.138 & & & 1.193 & 0.281 & & & & \\
\hline & 1.116 & & & & 0.792 & & & & & \\
\hline \multirow[t]{2}{*}{$\ln ($ age $)$} & -2.283 & -0.367 & & & & & $-2.422^{*}$ & $-0.5228^{*}$ & -2.029 & -0.402 \\
\hline & 1.897 & & & & & & 1.143 & & 1.835 & \\
\hline \multirow[t]{2}{*}{ Male D } & Dropped & & & & & & $2.440^{\dagger}$ & $0.3366^{* *}$ & Dropped & \\
\hline & & & & & & & 1.445 & & & \\
\hline \multirow[t]{2}{*}{ Afrikaans D } & -0.992 & -0.195 & & & & & $-2.0957^{* *}$ & $-0.4807^{* *}$ & -1.654 & -0.382 \\
\hline & 1.268 & & & & & & 0.8270 & & 1.222 & \\
\hline \multirow[t]{2}{*}{ Constant } & $-25.84^{*}$ & & $-26.38^{* *}$ & & 0.061 & & $8.320^{\dagger}$ & & -13.18 & \\
\hline & 12.64 & & 7.209 & & 1.036 & & 4.457 & & 9.896 & \\
\hline$n$ & 59 & & 69 & & 68 & & 75 & & 63 & \\
\hline Log likelihood & -23.34 & & -31.18 & & -39.91 & & -41.56 & & -26.42 & \\
\hline Pseudo $R^{2}$ & 0.392 & & 0.301 & & 0.068 & & 0.141 & & 0.369 & \\
\hline Wald LR & $\chi_{10}^{2}=25.17$ & $p=0.001$ & $\chi_{4}^{2}=19.32$ & $p=p=0.001$ & $\chi_{5}^{2}=5.34$ & $p=0.376$ & $\chi_{3}^{2}=10.23$ & $p=0.017$ & $\chi_{6}^{2}=22.46$ & $p=0.001$ \\
\hline Hosmer-Lemeshow & $\chi_{8}^{2}=6.16$ & $p=0.630$ & $\chi_{8}^{2}=8.80$ & $p=0.360$ & $\chi_{8}^{2}=4.17$ & $p=0.841$ & $\chi_{8}^{2}=4.82$ & $p=0.777$ & $\chi_{8}^{2}=5.78$ & $p=0.672$ \\
\hline
\end{tabular}

Significant at $p \leqslant 5 \%$.

Significant at $p \leqslant 10 \%$ 
Table 5

Selected estimation results using alternative specification on remnant variable.

\begin{tabular}{|c|c|c|c|c|c|c|}
\hline & \multicolumn{2}{|c|}{ Combined model } & \multicolumn{2}{|c|}{ Opportunity cost } & \multicolumn{2}{|c|}{ Opportunity cost + demographics } \\
\hline & $\begin{array}{l}\text { Coefficient } \\
\text { robust SE }\end{array}$ & Marginal effect & $\begin{array}{l}\text { Coefficient } \\
\text { robust SE }\end{array}$ & Marginal effect & $\begin{array}{l}\text { Coefficient } \\
\text { robust SE }\end{array}$ & Marginal effect \\
\hline \multirow[t]{2}{*}{$\ln$ (farm size) } & $0.818^{\dagger}$ & $0.103^{*}$ & $0.543^{*}$ & $0.089^{* *}$ & $0.489^{\dagger}$ & $0.089^{*}$ \\
\hline & 0.430 & & 0.229 & & 0.256 & \\
\hline \multirow[t]{2}{*}{$\%$ farm income } & $-2.292^{*}$ & $-0.289^{\dagger}$ & $-1.888^{*}$ & $-0.308^{*}$ & $-2.004^{*}$ & $-0.367^{*}$ \\
\hline & 0.982 & & 0.741 & & 0.807 & \\
\hline \multirow[t]{2}{*}{$\ln$ (education) } & $15.18^{* *}$ & $1.915^{* *}$ & $10.35^{* *}$ & $1.692^{* *}$ & $8.994^{* *}$ & $1.646^{* *}$ \\
\hline & 5.732 & & 3.116 & & 3.111 & \\
\hline \multirow[t]{2}{*}{ \% remnant } & $-4.512^{*}$ & $-0.569^{*}$ & $-2.835^{*}$ & $-0.463^{*}$ & $-2.757^{\dagger}$ & $-0.504^{*}$ \\
\hline & 2.088 & & 1.304 & & 1.498 & \\
\hline \multirow[t]{2}{*}{$\ln ($ family tenure) } & 0.766 & 0.097 & & & & \\
\hline & 0.494 & & & & & \\
\hline \multirow[t]{2}{*}{ Farmers' union D } & -1.405 & -0.226 & & & & \\
\hline & 1.119 & & & & & \\
\hline \multirow[t]{2}{*}{ Conservancy D } & 1.129 & 0.170 & & & & \\
\hline & 0.986 & & & & & \\
\hline \multirow[t]{2}{*}{ Tourism D } & $-4.890^{* *}$ & $-0.181^{\dagger}$ & & & & \\
\hline & 1.907 & & & & & \\
\hline \multirow[t]{2}{*}{ PA proximity D } & -1.390 & -0.128 & & & & \\
\hline & 1.134 & & & & & \\
\hline \multirow[t]{2}{*}{$\ln ($ age $)$} & -2.632 & -0.332 & & & -2.295 & -0.420 \\
\hline & 2.038 & & & & 1.868 & \\
\hline Male D & Dropped & & & & Dropped & \\
\hline \multirow[t]{2}{*}{ Afrikaans D } & -0.836 & -0.132 & & & -1.739 & -0.391 \\
\hline & 1.132 & & & & 1.178 & \\
\hline \multirow[t]{2}{*}{ Constant } & $-31.87^{*}$ & & $-28.24^{* *}$ & & $-13.87^{*}$ & \\
\hline & 14.47 & & 8.410 & & 10.60 & \\
\hline$n$ & 59 & & 69 & & 63 & \\
\hline Log likelihood & -22.03 & & -29.97 & & -25.86 & \\
\hline Pseudo $R^{2}$ & 0.426 & & 0.328 & & 0.382 & \\
\hline Wald LR & $\chi_{10}^{2}=20.83$ & $p=0.035$ & $\chi_{4}^{2}=16.35$ & 0.003 & $\chi_{6}^{2}=18.64$ & 0.005 \\
\hline Hosmer-Lemeshow & $\chi_{8}^{2}=5.74$ & $p=0.676$ & $\chi_{8}^{2}=3.87$ & 0.869 & $\chi_{8}^{2}=7.92$ & 0.441 \\
\hline
\end{tabular}

** Significant at $p \leqslant 1 \%$.

* Significant at $p \leqslant 5 \%$.

† Significant at $p \leqslant 10 \%$.

participation in conservation, five logit models were specified which use different combinations of opportunity cost, affiliation and demographics variables. Robust Huber-White sandwich estimators were used to account for heteroskedasticity (Baum, 2006). Three measures of goodness of fit were considered including Stata's pseudo $R^{2}$, a standard Wald Likelihood Ratio test and a Hosmer-Lemeshow test. For a meaningful model, the Wald hypothesis that all explanatory variables jointly add nothing had to be rejected. For a good fit the Hosmer-Lemeshow null hypothesis of no difference in actual and predicted distributions had to be not rejected.

In multivariate modelling multicollinearity is sometimes raised as a concern. No remedy is usually necessary as coefficients estimated in the presence of multicollinearity are still best and unbiased (Gujarati, 2003). High degrees of collinearity produce coefficient estimates with large variances and covariances, which in practice results in variables being dropped from models because they are not statistically significant. Clearly in this analysis there was a danger of judging variables to be unimportant for explaining conservation actions based on insignificant $t$-statistics when those $t$-statistics were low because of multicollinearity. To avoid this trap, correlation coefficients were inspected to check for excessive multicollinearity and where necessary alternative modelling strategies were considered.

\section{Results}

Participants in conservation were in the minority (35\%) in our sample. The results of pair-wise tests of significance appear in Table 2 . Average farm size was 1943 ha for participants and 1472 ha for non-participants; the difference was not statistically significant at $p \leqslant 0.05$. Although participants derived only $30 \%$ of their household income from traditional agriculture as compared to $48 \%$ for non-participants, the difference was not statistically significant at $p \leqslant 0.05$. The $t$-test on education indicated a significance level of $p \leqslant 0.05$; on average participants had 14 years of formal education, and non-participants had 11 years of education. The differences across participants and non-participants in the size of the remnant and the\%remnant variables were not statistically significant. None of the differences in identity variables except language status were statistically significant at $p \leqslant 0.05$. Of participants, $77 \%$ were Afrikaans speaking and of non-participants, 94\% were Afrikaans speaking. The differences in proximity to protected areas and gender were marginally significant $(p \leqslant 0.10)$. Of these, the difference in the proportion of participants and non-participants who held land next to a protected area was especially large; only $11 \%$ of nonparticipants were located next to a protected area while $28 \%$ of participants were located next to a protected area.

Most pair-wise correlations between the explanatory variables were mild or low as can be seen in Table 3. The only exception was the correlation between farm size and the size of the untransformed remnant, which produced a correlation coefficient of 0.866 . The alternative\%remnant specification was uncorrelated $(r=0.253)$ with total farm size.

The first set of estimation results in Table 4 is for a logit model in which opportunity cost variables were combined with affiliation variables. The second set of results is for a pure opportunity cost model, and the third and fourth set for a pure affiliation and pure demographics model respectively. Opportunity cost and demographic variables were combined in the fifth model. These models used remnant size to establish the marginal impact on 
conservation of each additional hectare of natural vegetation in private ownership. Although strongly correlated with total farm size, it should be noted that both variables were significant in all three models in which they were used.

The combined model produced a pseudo $R^{2}=0.392$ using 59 observations. The gender variable was dropped during estimation, which partly explained the low sample size. The Wald Likelihood Ratio test rejected the hypothesis that all explanatory variables jointly added no value and the Hosmer-Lemeshow statistic failed to reject a misspecification hypothesis. The coefficients on four variables and their marginal effects were statistically significant at $p \leqslant 0.05$. Three of the four the signs were as expected. The negative and statistically significant sign on the tourism dummy variable was more difficult to interpret. The most reasonable explanation is probably that the negative sign was an artefact of the measurement difficulties mentioned above. While we expected exposure to eco-tourism to be positively correlated with the propensity for conservation, the same was clearly not true of all tourism. Marginal effects identified education as the most important determinant of participation in conservation. A $1 \%$ increase in education corresponded to a $1.92 \%$ increase in the probability of participating in conservation. The next most influential variable was share of income from agriculture, where a one percentage point increase in the share of income from agriculture led to a $0.24 \%$ decrease in the probability of participating in conservation. A $1 \%$ increase in farm size was expected to result in a $0.17 \%$ increase in the likelihood of participation. A $1 \%$ increase in the size of the remnant was expected to result in a $0.09 \%$ decrease in the likelihood of participation. Together the last two results suggested affordability to be more important than opportunity cost in explaining the conservation decision on private land.

The pure opportunity cost model in Table 4 produced a pseudo $R^{2}=0.301$ using 69 observations. It passed both specification tests. Three of the four of the explanatory variables were significant at $p \leqslant 0.05$ and all carried the hypothesised signs. A $1 \%$ increase in farm size corresponded to a $0.13 \%$ increase in the propensity for conservation. This estimate was $27 \%$ smaller than the one estimated for the combined model. Share of income from agriculture had a marginal effect of -0.251 in the opportunity cost model, which was within $5 \%$ of the marginal effect estimated in the combined model. There was a difference of $16 \%$ in the estimates of the marginal effect of education, with the pure opportunity cost model yielding a smaller, but still elastic, marginal effect of 1.62 . A $1 \%$ increase in the size of the remnant produced a $0.06 \%$ decrease in the likelihood of conservation in the opportunity cost model, which was $32 \%$ smaller than the estimate from the combined model. For both the combined and pure opportunity cost models the marginal effect of the remnant was about half the size of the marginal effect of total farm size.

When affiliation and demographic variables were incorporated into a single identity model, the Wald Likelihood Ratio test produced a statistic $\chi^{2}(8)=10.37(p=0.240)$, which indicated misspecification. Misspecification was confirmed by a lack of significance on individual coefficients, which is why this set of results was not given in Table 4.

The pure affiliation model in Table 4 produced a pseudo $R^{2}=0.068$ using 68 observations. It failed the Wald Likelihood Ratio test $\left(\chi^{2}(8)=5.34, p>\chi^{2}=0.3759\right)$ and produced no coefficients which were statistically significant at $p \leqslant 0.05$.

Modelling participation with the natural logarithm of age, and male gender and Afrikaans language dummy variables produced a model with a pseudo $R^{2}=0.141$ which passed both specification tests. Two of the estimated coefficients and all three marginal effects in the demographics model were significant at $p \leqslant 0.05$. Age had an inelastic relationship with participation in conservation; a $1 \%$ increase in age was expected to reduce the likelihood of participation by $0.52 \%$. Male gender corresponded to a $34 \%$ increase in and Afrikaans-language status to a $48 \%$ decrease in the likelihood of conservation.

The final model in Table 4 introduced the three significant demographic variables back into the opportunity cost model. It produced a pseudo $R^{2}=0.369$ and passed both specification tests. Gender was dropped during estimation. Although the overall fit was slightly better than the one produced in the pure opportunity cost model, results revealed none of the demographic variables to be even marginally significant when combined with the opportunity cost variables. Coefficient estimates and marginal effects for the opportunity cost variables were somewhere between those estimated for the combined and pure opportunity cost models.

For completeness, the combined, pure opportunity cost and opportunity cost plus demographics models were re-estimated using the\%remnant variable. These results are presented in Table 5. Changing the specification of the remnant variable had very little impact on the results. The same patterns of signs and significances were recorded in both cases, and although there were differences in the magnitudes of individual coefficients, these differences were of the same order of magnitude as the differences between the rival sub-models. Where previously a $1 \%$ increase in the size of the remnant produced a marginal effect of $0.09 \%$ in the combined or $0.06 \%$ in the pure opportunity cost model, a one percentage point increase in the remnant's share of farm size produced marginal effects of 0.57 in the combined or 0.46 in the pure opportunity cost model for the\%remnant specification.

\section{Discussion}

Pair-wise comparisons and multivariable modelling explained conservation on private land differently. For example, education was the only opportunity cost variable to be significant in pairwise testing, while all four opportunity cost variables were at least marginally significant in multivariable models. Language, which was a significant discriminant of participation in a pair-wise test, was not significant in any of the multivariable models. In contrast, replacing the remnant size variable with a\% remnant variable had almost no effect on results.

Our results strongly suggest conservation to be a matter of finances and not of identity. In the combined model, opportunity cost variables overwhelmed factors which described landholder identity and affiliation. When modelled separately, the opportunity cost sub-model did almost as well as the combined model. Signs, significance levels and even the size of the estimated opportunity cost coefficients were reasonably robust across specifications. In contrast, identity variables as a group contributed almost nothing to the combined model. Affiliation variables failed to explain participation. Demographic variables only explained half as much as the opportunity cost model, but when combined with the opportunity cost model they were no longer significant. It can be concluded from these results that opportunity cost is much more powerful in explaining participation than any of the other variables normally used to do so. It is possible for age, gender and language simply to track patterns of opportunity cost on the Agulhas Plain, in which case the opportunity cost model has to be preferred to the demographics sub-model on the grounds of that it offers a motivation for participation in conservation instead of just identifying its covariates.

The positive sign on farm size when regressed against conservation found in this study was new. Other studies which found significant farm size effects, reported negative relationships between farm size and conservation (Sekhar, 2003; Shrestha and Alavalapati, 2006; Cross et al., 2011). Our result indicated affordability to be a constraint to conservation on private land. 
The coefficients on farm income and education confirmed previous results which identified opportunity cost as a discriminant of participation in conservation (Jacobson et al., 2003; Plieninger et al., 2004; Cross et al., 2011; Raymond and Brown, 2011), but explicitly interpreting education as a proxy for opportunity cost is new. While schooling may as a marker of identity, we argue that it also, perhaps more directly, affects a person's income and therefore his or her opportunity cost of conservation. The larger, although not significantly larger, mean size of the remnant recorded for participants in pair-wise test, produced results in line with a finding for renosterveld conservation elsewhere the Cape Floristic Region (Winter et al., 2005). However, in the multivariate model the coefficient on size of the remnant switched signs, revealing landholders with larger untransformed areas to be consistently less inclined towards conservation than landholders with smaller untransformed areas. Michael (2003) would interpret this finding as evidence of agricultural land uses being more profitable than conservationcompatible land uses.

The obvious implication of finances being the main determinant of conservation on private land is that compensation might be needed to meet conservation targets. Unfortunately designing the right scheme is not so simple. Many schemes exist the world over, but significant concerns around cost and conservation effectiveness have been raised for most of them, whether they involve compensation for livestock losses (e.g. Bulte and Rondeau, 2005) or conservation easements as they exist in North America or France (e.g. Merenlender et al., 2004; Princé et al., 2012). However, just because this topic needs further work, it does not mean that compensation can be announced to be irrelevant or unimportant.

Surprisingly landholder affiliation did not seem to matter for participation in conservation on private land. This was especially true of conservancy membership, for which strong evidence of a positive relationship with conservation exists (Jacobson et al., 2003; Plieninger et al., 2004; Winter et al., 2005; Lindsey et al., 2005; Cross et al., 2011). In retrospect, farmers' union membership could hardly be significant since almost everyone we interviewed belonged to it. Similarly, our unexpected tourism result might be due to the universally low prevalence of tourism operators in our sample, rather than a fundamental difference between tourism operators and others. Previous evidence on how proximity to a protected area shapes conservation attitudes is mixed (Shrestha and Alavalapati, 2006; Sekhar, 2003). We found protected area proximity to be significantly higher for participants than for nonparticipants in a pair-wise test, but the result did not persist in multivariate models, which leaves the issue of proximity to protected areas unresolved. We know anecdotally that some farmers signed up for the Landscape Initiative in order to secure their land against expropriation for conservation or land reform. Our result on age was consistent with previous findings (Jacobson et al., 2003; Sekhar, 2003; Lindsey et al., 2005). Our result on gender was surprising as female gender is usually associated with greater conservation-mindedness (Jacobson et al., 2003; Raymond and Brown, 2011), but it should be noted that our sample consisted mostly of males. We found participants to be more likely to be English-speaking than non-participants, as previously recorded by Lindsey et al. (2005). In the demographics sub-model, being Afrikaans-speaking was associated with a $48 \%$ lower probability of engaging in conservation than being English-speaking. The farming community is predominantly Afrikaans-speaking, while the business of the environmental lobby and the post-apartheid South African government is conducted almost exclusively in English. We interpret the strong negative response to a feeling of discomfort on the part of Afrikaans-speaking farmers and a desire to put up resistance both against the government and against different (conservation) values.
The implications of these results for conservation on private land are simple: Take on board the importance of landholders' livelihoods in their conservation decisions on their land. Understand that conservation might impose unfair actual or perceived costs on local landholders (Michael, 2003; Balmford and Whitten, 2003), which not everyone would be prepared to bear. Embed the likelihood of participation into the spatial conservation planning model for an area and focus outreach on landholders shown to have a high probability of participation. Conduct meetings in the home language of the community, as farmers are already being asked to make a mind shift to even consider conservation. Where evidence predicts no-one to be likely to sign up for conservation, consider ways in which to reduce the opportunity cost of participation, for example, by introducing compensation.

\section{Conclusion}

This study asked how much financial circumstance, such as wealth and forgone income, mattered for landholders' involvement in conservation on private land. We found opportunity cost variables to matter more than any of the other factors typically used to explained conservation-mindedness. These results therefore demonstrate the need to understand a farmer's ability to invest in conservation if private land is going to contribute significantly to conservation targets.

\section{Acknowledgements}

Funding by Fauna and Flora International's Arcadia Fund is gratefully acknowledged, as is the input from two anonymous reviewers. We also thank ABI, in particular Tertius Carinus, Hennis Germishuys and Lesley Richardson for their interest in and assistance with the project.

\section{Appendix A. Supplementary material}

Supplementary data associated with this article can be found, in the online version, at http://dx.doi.org/10.1016/j.biocon.2012.08.028. These data include Google maps of the most important areas described in this article.

\section{References}

Balmford, A., Whitten, T., 2003. Who should pay for tropical conservation, and how could the costs be met? Oryx $37,238-250$.

Baum, C.F., 2006. An Introduction to Modern Econometrics using Stata. Stata Press, Texas.

Brooks, T.M., Bakarr, M.I., Boucher, T., da Fonseca, G.A.B., Hilton-Taylor, C., Hoekstra, T., Moritz, J.M., Olivier, S., Parrish, J., Pressey, R.L., Rodrigues, A.S.L., Sechrest, W., Stattersfield, A., Strahm, W., Stuart, S.N., 2004. Coverage provided by the global protected-area system: is it enough? Bioscience 54, 1081-1091.

Bulte, E.H., Rondeau, D., 2005. Why compensating wildlife damages may be bad for conservation. J. Wildl. Manage. 69, 14-19.

Conradie, B., 2010. Farmers' views of landscape initiatives: the case of the Agulhas Plain, CFR. Working paper 278, Centre for Social Science Research, University of Cape Town. <http://www.uct.ac.za/CSSR>.

Cowling, R.M., Holmes, P.M., 1992. Endemism and speciation in a lowland flora from the Cape Floristic Region. Biol. J. Linn. Soc. Lond. 47, 367-383.

Cowling, R.M., Mustart, P.J., 1994. Vegetation and conservation. Volume 2 Appendix 5. MLH Architects and Planners, Cape Town.

Cross, J.E., Keske, C.M., Lacy, M.G., Hoag, D.L.K., Bastian, C.T., 2011. Adoption of conservation easements among agricultural landowners in Colorado and Wyoming: the role of economic dependence and sense of place. Landscape Urban Plann. 101, 75-83.

Gallo, J.A., Pasquini, L., Reyers, B., Cowling, R.M., 2009. The role of private conservation areas in biodiversity representation and target achievement within the Little Karoo region, South Africa. Biol. Conserv. 142, 446-454.

Gujarati, D.N., 2003. Basic Econometrics. fourth ed. McGraw Hill, Boston.

Jacobson, S.K., Sieving, K.E., Jones, G.A., van Doorn, A., 2003. Assessment of farmer attitudes and behavioural intentions toward bird conservation on organic and conventional Florida farms. Conserv. Biol. 17, 595-606. 
Knight, A.T., Cowling, R.M., Boshoff, A.F., Wilson, S.L., Pierce, S.M., 2011. Walking in STEP: lessons for linking spatial prioritisations to implementation strategies. Biol. Conserv. 144, 202-211.

Knight, R.L., 1999. Private lands: the neglected geography. Conserv. Biol. 13, 223 224.

Lindsey, P.A., du Toit, J.T., Mills, M.G.L., 2005. Attitudes of ranchers towards African wild dogs Lycaon pictus: conservation implications on private land. Biol. Conserv. 125, 113-121.

Lochner, P., Weaver, A., Gelderblom, C., Paert, R., Sandwith, T., Fowkes, S., 2003. Aligning the diverse: the development of a biodiversity conservation strategy for the Cape Floristic Region. Biol. Conserv. 112, 29-43.

Lombard, A.T., Cowling, R.M., Pressey, R.L., Mustart, P.J., 1997. Reserve selection in a species-rich and fragmented landscape on the Agulhas Plain. South Africa. Conservation Biology 11, 1101-1116.

Ma, H., Lu, Y., Xing, Y., He, G., Sun, Y., 2009. Rural households' attitude and economic strategies toward the conversion of cropland to forest and grassland Program (CCFG): a case study in Qira, China. Environ. Manage. 43, 1039-1047.

Merenlender, A.M., Huntsinger, L., Guthey, G., Fairfax, S.K., 2004. Land trusts and conservation easements: who is conserving what for whom? Conserv. Biol. 18 65-75.

Michael, J.A., 2003. Efficient habitat protection with diverse landowners and fragmented landscapes. Environ. Sci. Policy 6, 243-251.

Plieninger, T., Modolell y Mainou, J., Konold, W., 2004. Land manager attitudes toward management, regeneration, and conservation of Spanish holm oak savannas (dehesas). Landscape Urban Plann. 66, 185-198.

Pressey, R.L., 1994. Ad hoc reservations: forward or backward steps in developing representative reserve systems? Conserv. Biol. 8, 662-668.
Princé, K., Moussus, J.P., Jiguet, F., 2012. Mixed effectiveness of French agrienvironmental schemes for nationwide farmland bird conservation. Agric. Ecosyst. Environ. 149, 74-79.

Raimondo, D., von Staden, L., Foden, W., Victor, J.E., Helme, N.E., Turner, R.C., Kamundi, D.A., Manyama, P.A., 2009. Red List of South African plants 2009. Strelitzia 25, South African National Biodiversity Institute, Pretoria.

Raymond, C.M., Brown, G., 2011. Assessing conservation opportunities on private land: socio-economic, behavioural and spatial dimensions. J. Environ. Manage. 92, 2513-2523.

Richards, C., Lawrence, G., Kelly, N., 2005. Beef production and the environment: is it really 'Hard to be green when you are in the red'? Rural Society 15, 192-209.

Rodriques, A.S.L., Andelman, S.J., Bakarr, M.I., Boitani, L., Brooks, T.M., Cowling, R.M. Fishpool, L.D.C., da Fonseca, G.A.B., Gaston, K.J., Hoffmann, M., Long, J.S., Margquet, P.A., Pilgrim, J.D., Pressey, R.L., Schipper, J., Sechrest, W., Stuart, S.N., Underhill, L.G., Waller, R.W., Watts, M.E.J., Yan, X., 2004. Effectiveness of the global protected area network in representing species diversity. Nature 428 640-643.

Sekhar, N.U., 2003. Local people's attitudes towards conservation and wildlife tourism around Siriska Tiger Reserve, India. J. Environ. Manage. 69, 339-347.

Shrestha, R.K., Alavalapati, J.R.R., 2006. Linking conservation and development: an analysis of local people's attitude towards Koshi Tappu wildlife reserve, Nepal. Environ. Develop. Sustain. 8, 69-84.

Winter, S.J., Esler, K.J., Kidd, M., 2005. An index to measure the conservation attitudes of landowners towards Overberg Coastal renosterveld, a critically endangered vegetation type in the Cape Floral Kingdom, South Africa. Biol. Conserv. 126, 383-394. 